\title{
VIVÊNCIAS DO LAZER PARA DISCENTES DO CURSO DE EDUCAÇÃO FÍSICA DA UNIVERSIDADE FEDERAL DO PARÁ NO CONTEXTO DE PANDEMIA DA COVID - $19^{1}$
}

Recebido em: 07/08/2020

Aprovado em: 01/09/2020

Licença: @) (1) @

\author{
Lucília da Silva Matos ${ }^{2}$ \\ Welington da Costa Pinheiro ${ }^{3}$ \\ Mirleide Chaar Bahia ${ }^{4}$ \\ Universidade Federal do Pará (UFPA) \\ Belém - PA - Brasil
}

RESUMO: O estudo objetiva analisar as vivências de lazer de discentes do curso de Educação Física da Universidade Federal do Pará, no contexto da pandemia da COVID19. A metodologia da pesquisa é descritiva e de abordagem quali-quantitativa. O instrumento foi um questionário produzido e enviado via Google Forms. Participaram da pesquisa 104 discentes. Os dados foram sistematizados no programa Microsoft Excel. Os resultados da pesquisa apontaram que: o envolvimento com as atividades de lazer diminuiu para a maioria dos discentes; os afazeres domésticos e os estudos e cursos online foram as atividades obrigatórias mais realizadas; as interações por meio de redes sociais e assistir séries foram os interesses de lazer mais mencionados; e que, embora um percentual de discente tenha adaptado e/ou criado novas atividades de lazer, em sua maioria isso não foi possível no contexto da pandemia da COVID-19.

PALAVRAS-CHAVE: Atividades de Lazer. Pandemia da Covid-19. Discentes de Educação Física.

\section{LEISURE EXPERIENCES FOR STUDENTS OF THE PHYSICAL EDUCATION DEGREE COURSE OF THE FEDERAL UNIVERSITY OF PARÁ IN THE}

\footnotetext{
${ }^{1}$ Este artigo é proveniente de dados preliminares do Projeto de pesquisa Vivências e Barreiras do Lazer em tempos de pandemia: um estudo com os (as) discentes do curso de Educação Física - Universidade Federal do Pará, Campus Belém, vinculado ao Grupo de Pesquisa Lazer e Ludicidade na Amazônia (MOÇARAI) e do Centro de Desenvolvimento em Políticas Públicas de Esporte e Lazer da Rede Cedes do Estado do Pará/UFPA (CEDES-PA).

${ }^{2}$ Docente da Faculdade de Educação Física - Instituto de Ciências da Educação, Universidade Federal do Pará. Doutora. Coordenadora e pesquisadora do Centro de Desenvolvimento de Pesquisa em Política Pública de Esporte e Lazer da Rede Cedes do Pará.

${ }^{3}$ Docente da Faculdade de Educação Física - Instituto de Ciências da Educação, Universidade Federal do Pará. Doutor. Pesquisador colaborador do Centro de Desenvolvimento de Pesquisa em Política Pública de Esporte e Lazer da Rede Cedes do Pará.

${ }^{4}$ Docente do Programa de Pós-graduação em Desenvolvimento Sustentável do Trópico Úmido, do Núcleo de Altos Estudos Amazônicos, da Universidade Federal do Pará. Doutora. Pesquisadora e Coordenadora adjunta do Centro de Desenvolvimento de Pesquisa em Política Pública de Esporte e Lazer da Rede Cedes do Pará.
} 


\section{CONTEXT OF THE COVID-19 PANDEMIC}

ABSTRACT: The study aims to analyze the leisure experiences of students from the Physical Education undergraduate course at the Federal University of Pará, in the context of the COVID-19 pandemic. The methodology of research is descriptive and of qualitative and quantitative approach. The instrument was a questionnaire produced and sent via the Google Forms. The survey involved 104 students. After receiving the questionnaires, the data was systematized in the Microsoft Excel program. The survey results pointed out that: the involvement with leisure activities decreased for most students; domestic tasks and online studies and courses were the most mandatory activities performed during; interactions through social networks and watching TV series were the most mentioned leisure interests;; and that, although a percentage of students adapted and/or created new leisure activities, for the most part it was not possible in the context the COVID-19 pandemic.

KEYWORDS: Leisure Activities. Covid-19 Pandemic. Physical Education Degree Students.

\section{A Pandemia da Covid-19 e o Lazer: Uma Introdução}

As autoridades políticas não deram importância até morrer gente. Havia dificuldades de enterrar os mortos, pois eram mais de mil por dia. No sistema de saúde, “[...] faltavam leitos, ambulâncias, material médico e profissionais adequados" (DEL PRIORI, 2017, p. 495). Apenas quando tudo se alastrou, postos e hospitais de emergência foram construídos em diferentes pontos do país.

As notícias dos jornais espalhavam os horrores daquele tempo. Por outro lado, “[...] as autoridades preferiam censurar a imprensa. Nada de más notícias! Mas pessoas morriam como moscas, o desabastecimento das capitais aumentava, as cidades em pânico e o sistema público parado (DEL PRIORI, 2017, p. 495). As cidades praticamente pararam “[...] foram fechadas as escolas e as faculdades de Direito e Medicina, clubes e casas de diversão. Eventos foram suspensos e se alguém espirrasse, os demais se afastavam rápido. Sem comércio, nem empregados, crescia a especulação e a carestia" (DEL PRIORI, 2017, p. 495).

O contexto apresentado no escrito da historiadora Mary Del Priore, com base em documentos do período, ilustra os impactos da pandemia da Gripe Espanhola que assolou

licere, Belo Horizonte, v.23, n.3, set/2020. 
o planeta entre os anos de 1918 e 1919, tendo sido originada da mutação do vírus Influenza. Essa doença deixou grandes lastros de vidas perdidas por quase todo o mundo. No Brasil, foram milhares de óbitos, apenas na sua então capital, Rio de Janeiro, registrou-se mais de 14 mil mortes (KOLATA, 2002). No Pará, os registros são imprecisos e contraditórios, o que gerou a subnotificação dos casos, em razão da precária condição do sistema de saúde e da ingerência do poder público da época, porém se estima o quantitativo de mais de dois mil óbitos somente na cidade de Belém (ABREU JR, 2018).

A realidade pela qual o Brasil passava no início do século $\mathrm{XX}$ poderia muito bem retratar o país da atualidade, que se encontra em um contexto de pandemia provocada pelo Coronavírus SARS-CoV-2.A menção a esse capítulo da história permite refletir o quanto os problemas que afligem a população brasileira, sobretudo, a parcela menos favorecida, estão enraizados na constituição sócio-histórica do país, possibilitando, assim, pontuar o quanto o Brasil, ainda hoje, carece de condições mínimas de dignidade e está longe de garantir os direitos constitucionais básicos à população. Além disso, chama atenção que o posicionamento das autoridades políticas há 112 anos, na pandemia da Gripe Espanhola, assemelha-se à postura adotada pelo Presidente da República em pleno ano de 2020, o que dá indícios de que o descaso e a irresponsabilidade parecem ser constantes frente às graves crises vividas pelo país ao longo de sua historiografia.

O Coronavírus SARS-CoV-2 surgiu na cidade de Wuhan, na China, alastrando-se nos primeiros meses do ano de 2020 para os seis continentes, por meio de sua potente e rápida capacidade de contaminação. A COVID-19, nomenclatura mais conhecida, provocou uma crise de proporções internacionais, com dezenas, centenas e logo milhares de pessoas mortas por dia em todo o mundo, fato que levou a Organização Mundial de Saúde (OMS) a declarar em 11 de março de 2020, que se tratava de uma pandemia. Os países que conseguiram compreender a sua dimensão e gravidade, logo deram início a 
um conjunto de medidas para contê-la, como o fechamento de fronteiras, a determinação de quarentena, isolamento e distanciamento social, a aplicação de testes de detecção em massa, o estabelecimento de protocolos de higiene, entre outras.

No Brasil, a COVID-19 teve seu primeiro caso confirmado no dia 26 de fevereiro de 2020, na cidade de São Paulo e logo se disseminou em uma conjuntura nada favorável, na qual a população já se encontrava em extrema vulnerabilidade, com taxas altas de desemprego e significativos cortes nas políticas sociais (WERNECK; CARVALHO, 2020). Aliado a isso, instaurou-se uma crise de ordem política e econômica, pois enquanto alguns governadores e prefeitos demonstram certo comprometimento com a vida humana, empenhando-se na eficácia de uma política de distanciamento social visando amenizar o contágio da COVID-19, o Presidente da República não levou em consideração os parâmetros adotados pela Organização Mundial da Saúde (OMS) para conter a pandemia, ignorando a gravidade do vírus. Esse, por sua vez, adotou o discurso de um suposto isolamento vertical, revelador de uma concepção eugênica de inspiração nazista, na qual pressupõe que os fracos devem ficar em casa e os fortes devem sair para o trabalho, como se fosse possível separar e não ter contato com os sujeitos que denomina de fortes e fracos (DINO, 2020).

O Estado do Pará teve a confirmação do primeiro caso de COVID-19 em 18 de março de 2020; no dia 19, foi registrada a primeira morte, na Vila de Alter do Chão, em Santarém, oeste paraense. Os meses de abril e maio corresponderam ao período de maior número de infectados e óbitos no estado, com as cidades de Breves, Castanhal, Belém e Marabá apresentando os maiores percentuais de infectados. A primeira, pertencente ao arquipélago do Marajó, foi uma das cidades que mais apresentou casos de COVID-19 em todo o país, com percentual de $24,8 \%$, revelando que aproximadamente 25 mil,dos 103 
mil habitantes da cidade de Breves, já haviam sido infectados, conforme o estudo intitulado EPCOVD19, da Universidade Federal de Pelotas (UFPEL, 2020).

Os impactos da COVID-19 na Amazônia têm vinculação direta com as condições de vida da população, pois a maioria de suas cidades carece de políticas, serviços, equipamentos, infraestrutura, profissionais de diversas áreas, entre outros, o que inviabiliza a garantia de direitos básicos aos sujeitos que vivem em meio aos campos, comunidades, florestas, rios, vilas e áreas urbanas distribuídas no extenso território paraense.Essa realidade contribui para que algumas cidades amazônicas, segundo dados do Instituto Brasileiro de Geografia e Estatística (IBGE), ocupassem a lista dos piores Índices de Desenvolvimento Humano (IDH) do país, a exemplo da já citada cidade de Breves (IBGE, 2020).

Os problemas de saúde pública enfrentados pelas cidades da região amazônica dificultam a realização de testes, a notificação de casos e o tratamento de infectados pela COVID-19. A própria Região Metropolitana de Belém ${ }^{5}$ já demonstra traços da precária condição vivida pela população, quando se nota que a média de leitos por mil habitantes é de apenas 1,78, inferior ao já baixo número da média nacional,que equivale a1,95 leitos para cada mil pessoas. Tudo isso contribui para a subnotificação dos registros da pandemia, o que significa dizer que o número de casos é bem maior do que se tem divulgado. Na cidade de Belém, especificamente, estima-se que o total de infectados seja vinte vezes maior do que os registros oficiais, conforme estudo que analisou a evolução da pandemia de COVID-19 no Pará, realizado pela Universidade Federal do Pará (UFPA, 2020).

\footnotetext{
${ }^{5}$ A Região Metropolitana de Belém é formada por sete cidades: Belém, Ananindeua,Marituba Benevides, Santa Bárbara do Pará e Santa Isabel do Pará e Castanhal. Estas concentram cerca de 2.459.321 do número total habitantes do Estado do Pará (IBGE, 2019).
}

licere, Belo Horizonte, v.23, n.3, set/2020. 
Atualmente $^{6}$, as informações oficiais dos órgãos de saúde, considerando os primeiros dias do mês de agosto, apontam que o Pará já soma 167.099 de casos confirmados e o quantitativo de 5.871 de óbitos ocasionados pela COVID-19, de acordo com o Boletim da Vigilância Epidemiológica da Secretária de Saúde do Pará (SESPA). No Brasil, nesse mesmo período, o Ministério da Saúde computou 2.962 .442 pessoas infectadas e 99.572 óbitos. Já o Consórcio de Veículos de Imprensa ${ }^{7}$, que divulga os números compilados das secretárias de saúde dos estados registrou o número de 2.967 .064 infectados e de 99.702 óbitos pela pandemia da COVID-19.

O avanço da pandemia no país fez com que estabelecimentos e serviços de diversas naturezas recebessem de estados e municípios, ao contrário do que defendia o Governo Federal, a recomendação de suspensão de suas atividades, exceto os chamados serviços essenciais (dentre os quais bancos, farmácias e supermercados), como medida preventiva de combate à pandemia, na intenção de promover o distanciamento social entre as pessoas, evitando-se, assim, aglomeração e a facilitação de contágio em espaços abertos e fechados. Além disso, adotaram-se medidas recomendadas pela OMS como lavar as mãos com água e sabão ou usar álcool gel e usar máscaras, se tiver que sair de casa, a fim de conter a propagação do vírus.

No âmbito educacional, instituições de ensino de variados níveis também suspenderam suas ações de ensino, pesquisa e extensão. A Universidade Federal do Pará, por exemplo, paralisou suas atividades no dia 19 de março de 2020, levando a comunidade universitária a entrar em situação de afastamento da rotina acadêmica, porém a situação de distanciamento promovida em tempos de pandemia implica na mudança ou

\footnotetext{
${ }^{6}$ Os dados da COVID-19 foram coletados das respectivas fontes no dia 07 de agosto de 2020.

${ }^{7}$ O Consórcio foi uma iniciativa dos veículos Folha de São Paulo, O Estado de São Paulo, Extra, O Globo, G1 e UOL para divulgar os números da pandemia da COVID-19, diretamente coletados das secretarias estaduais de saúde. O seu surgimento se configurou como resposta a Presidência do Brasil que atrasou boletins sobre a doença, retirou informações para a consulta de sites e divulgou dados conflitantes.
}

licere, Belo Horizonte, v.23, n.3, set/2020. 
ressignificação de tantos outros afazeres que compõem a vida cotidiana, como as atividades da esfera econômica, religiosa, esportiva, educacional e de lazer, o que pressupõem a adequação ou criação de novas dinâmicas na rotina diária dos sujeitos. Essa alteração abrupta ocasionada pelo avanço da COVID-19 fez com que muitas pessoas, das mais diferentes idades, ficassem suscetíveis a problemas de saúde (SCHMIDT et al., 2020).

A pandemia da COVID-19 enfatizou ainda mais a necessidade de garantia de direitos constitucionais para uma vida com dignidade, como saúde, educação e moradia, mas também evidenciou que a arte, o esporte e o lazer, em certos casos tratados como supérfluos, são essenciais na formação humana. No caso do lazer, concebido enquanto cultura humana vivenciada no tempo livre (BAHIA, 2014), o distanciamento social limitou as suas manifestações em sociedade e, por conseguinte, a inter-relação entre os sujeitos, tendo em vista que o lazer “[...] como um fenômeno cultural, é responsável pela potencialização de redes de sociabilidade, em que grupos se organizam ampliando a rede de troca e enriquecendo a experiência pessoal e coletiva” (MATOS, 2001, p 123).

As restrições impostas pela pandemia, bem como as alterações por ela ocasionadas fizeram com que o ambiente doméstico passasse a ser o espaço onde a maioria das atividades fosse realizada. Nesse contexto, tem-se o lar como "[ [... o principal equipamento não específico de lazer” (MARCELLINO, 1996, p. 30), o que não teria como ser diferente, posto que o lazer é uma dimensão da vida humana. O lar, mesmo que ofereça condições desiguais, constitui-se “[...] um dos poucos equipamentos disponíveis para grandes parcelas da população" (MARCELLINO, 1996, p. 29), embora se tenha clareza de que as condições objetivas de vida são determinantes para os limites e as possibilidades de vivências do lazer. 
Essa lógica pode ser ilustrada por Bezerra et al. (2020) que, ao investigarem os fatores associados ao comportamento da população durante o isolamento social na pandemia da COVID-19, identificaram a correlação entre qualidade habitacional, renda e prática de atividades físicas, pois se verificou que para os sujeitos que declararam residirem em moradias consideradas ótimas e que possuíam a maior renda disseram que estavam realizando atividades físicas; por outro lado, aqueles que consideraram a qualidade de suas habitações como ruim ou péssima e que não têm renda alguma, declararam não estarem fazendo atividades físicas.

A pandemia da COVID-19 ressaltou que os modos de se relacionar com o trabalho, o consumo, o lazer e a convivência variam em predominância conforme a época, embora as mudanças passem, normalmente, quase sem perceber. Entretanto, a interrupção por uma pandemia não tem como passar despercebida, pois exige mudanças drásticas.O que nunca foi possível, passa a ser: ficar em casa, cuidar das tarefas domésticas,voltar a ter tempo para ler um livro, ficar com a família, o que nos faz refletir que“[...] a ideia conservadora de que não há alternativa ao modo de vida imposto pelo hipercapitalismo em que vivemos, cai por terra" (SANTOS, 2020, p. 46).

Entendendo-se “[...] o lazer como um dos maiores fenômenos da esfera da cultura" (MATOS, 2001, p. 122), evidencia-se que ele é, dialeticamente, processo e produto das relações humanas e, por isso, está envolvido na trama das relações e contradições sociais, posto que sua história no Ocidente, na Modernidade, mostra que ele já nasce como fruto das mudanças nas relações de trabalho, como reivindicação e conquista dos trabalhadores no início da industrialização, por um tempo livre do trabalho. E como um fenômeno oriundo das contradições do mundo do trabalho ele já nasce inundado por valores diferenciados sobre esse "tempo livre" (MATOS, 2001). 
O lazer, portanto, é compreendido nesse estudo como um espaço de vivências culturais de um tempo "livre", mas relacional com as obrigações profissionais, religiosas, fisiológicas, escolares, familiares e sociais. De modo que se pode pensá-lo na engrenagem entre a dimensão "tempo" e a dimensão "atitude” (MARCELLINO, 1996). Esta última pode ser entendida como desejo, vontade. Sabe-se, porém, que ter tempo livre não significa, necessariamente, ter disponibilidade para as vivências do lazer, pois além das obrigações que, muitas vezes, se impõe nesse tempo "livre", faz-se necessário também ter condições, disposição, querer, ter atitude, saúde, entre outros.

Tomando como referência o cenário complexo e incerto trazido pelos impactos desencadeados pela crise sanitária e pandêmica que assolou os tempos atuais, o presente estudo objetiva analisar as vivências de lazer de discentes do curso de Educação Física, da Universidade Federal do Pará, campus Belém, no contexto da pandemia da COVID19. Tal investigação se apresenta como relevante, pois traz contribuições para a discussão sobre como o lazer, o direito social e a vivência fundamental para a formação humana, manifestam-se em uma situação tão peculiar como a de uma pandemia, que pressupõe confinamento, distanciamento, paralisação e alterações de várias atividades em sociedade.

\section{Caminhos Traçados para a Compreensão das Vivências de Lazer dos Estudantes com o Distanciamento Social}

A presente pesquisa é de natureza descritiva e de abordagem quali-quantitativa. Sobre isso, destaca-se que a junção dessas duas abordagens (qualitativa e quantitativa) não são tratadas como opostas, mas sim complementares para a análise dos dados (MINAYO, 2003). 
O instrumento de coleta de dados foi um questionário composto por perguntas abertas e fechadas. O questionário pode ser definido, segundo Gil (1999, p.128), “[...] como a técnica de investigação composta por um número ou mais ou menos elevado de questões apresentadas por escrito às pessoas", cujo objetivo é conhecer as opiniões, crenças, interesses, situações vivenciadas, expectativas etc. As perguntas foram direcionadas para que fossem respondidas com base nos meses de pico da pandemia e de maiores taxas de distanciamento social no Estado do Pará, abril e maio. O período de aplicação do instrumento foi de 19 de junho a 10 de julho de 2020.

As perguntas do questionário foram estruturadas em três eixos: I- Perfil socioeconômico; II - Saúde no período de distanciamento social; e III - Hábitos relacionados ao uso do tempo durante o distanciamento social, apresentando questões sobre suas atividades diárias (obrigatórias e de lazer). Para atender ao objetivo delimitado para este estudo, realizou-se um recorte dos dados coletados, selecionando-se apenas perguntas pertencentes aos eixos I e II.

O questionário foi elaborado no aplicativo de gerenciamento de pesquisa Google Forms. Inicialmente, traz uma síntese da pesquisa e, em seguida, apresenta o Termo de Consentimento Livre e Esclarecido (TCLE), informando os objetivos, procedimentos e aspectos éticos do estudo, elucidando os fins exclusivamente acadêmicos da pesquisa e a garantia da preservação da identidade dos discentes. Após a leitura do TCLE, o instrumento fornece as opções de aceitar ou não a participação na pesquisa, o que em caso positivo significa que o discente está de acordo com os termos do estudo.

Os sujeitos da pesquisa foram 104 discentes do curso de Licenciatura em Educação Física, da Universidade Federal do Pará, campus Belém, cujos critérios de inclusão e exclusão foram: a- discentes matriculados no Curso de Educação Física no $1^{\circ}$ semestre 
Vivências do Lazer para Discentes do Curso de Educação Física da Universidade Federal do Pará no Contexto de Pandemia da Covid - 19

Lucília da Silva Matos; Welington da Costa Pinheiro e Mirleide Chaar Bahia

de 2020; e b- discentes que vivenciaram o distanciamento social em residência no Estado do Pará. A Tabela 01 expressa o perfil dos discentes que participaram da pesquisa:

Tabela 1: Perfil dos discentes participantes da pesquisa.

\begin{tabular}{|c|c|c|c|}
\hline PERGUNTAS & RESPOSTAS & $\mathbf{N}^{\circ}$ & $(\%)$ \\
\hline \multirow[b]{2}{*}{ Sexo biológico } & Feminino & 27 & $25,6 \%$ \\
\hline & Masculino & 77 & $74,4 \%$ \\
\hline \multirow{5}{*}{ Idade } & $15-19$ anos & 15 & $14,4 \%$ \\
\hline & $20-24$ anos & 63 & $60,5 \%$ \\
\hline & $25-29$ anos & 16 & $15,3 \%$ \\
\hline & $30-34$ anos & 06 & $5,7 \%$ \\
\hline & 35 ou + anos & 04 & $3,8 \%$ \\
\hline \multirow{3}{*}{ Estado civil } & Solteiro (a) & 93 & $84 \%$ \\
\hline & União estável & 07 & $6,7 \%$ \\
\hline & Casado (a) & 04 & $3,8 \%$ \\
\hline \multirow{5}{*}{ Tipo de moradia } & Casa própria & 65 & $62,5 \%$ \\
\hline & Casa cedida & 19 & $18,3 \%$ \\
\hline & Casa alugada & 10 & $9,6 \%$ \\
\hline & Apartamento próprio & 04 & $3,8 \%$ \\
\hline & Apartamento alugado & 06 & $5,8 \%$ \\
\hline \multirow{4}{*}{ Renda familiar } & Menos de 1 salário & 09 & $8,7 \%$ \\
\hline & Entre 1 e 3 salários & 65 & $62,5 \%$ \\
\hline & Entre 4 e 7 salários & 27 & $26 \%$ \\
\hline & Entre 8 e 11 salários & 03 & $2,9 \%$ \\
\hline
\end{tabular}

Fonte: Pesquisa autoral.

Os dados do questionário revelam que a maioria $(74,4 \%)$ dos discentes participantes da pesquisa é do sexo masculino. A faixa etária de 20-25 anos (60,5\%) abrange a maior parcela dos discentes, o que indica se tratar de um público basicamente composto por jovens. Em relação ao estado civil, o maior quantitativo (84\%) informou ser solteiro (a). Quanto ao tipo de moradia, o maior percentual $(62,5 \%)$ indicou que residem em casa própria. Por fim, no que tange à renda familiar, os discentes, majoritariamente $(62,5 \%)$, apontaram que se enquadram entre 1 e 3 salários mínimos, o que mostra o baixo nível econômico das famílias.

O instrumento foi enviado de forma online aos discentes que atendessem os critérios da pesquisa. Para tanto, realizou-se o contato via aplicativo de mensagem Whatsapp com cada um dos representantes das quatro turmas do curso de Educação Física da UFPA - Belém, ocasião na qual se apresentou a que se propunha a investigação e foi

licere, Belo Horizonte, v.23, n.3, set/2020. 
Vivências do Lazer para Discentes do Curso de Educação Física da Universidade Federal do Pará no Contexto de Pandemia da Covid - 19

Lucília da Silva Matos; Welington da Costa Pinheiro e Mirleide Chaar Bahia

feita a solicitação para esses encaminhassem o link que dá acesso ao questionário aos grupos de whatsapp de suas respectivas turmas, assim como que estimulassem os discentes a enviarem o instrumento devidamente preenchido.

Após o término do período de aplicação dos questionários, os dados numéricos foram sistematizados no programa Microsoft Excel, resultando em gráficos, quadros e tabelas e posteriormente passaram por análise.

\section{O Lazer na Pandemia da Covid-19: Vivências de Discentes do Curso de Educação}

\section{Física da UFPA/Belém}

Enquanto uma necessidade humana e uma dimensão da cultura (GOMES, 2014), o lazer se manifesta a partir da sua relação com os vários elementos que o condicionam e dinamizam: os interesses, os espaços, os equipamentos, os sentidos, os conteúdos, as atividades laborais, o tempo, os sujeitos, ou seja, os limites e as possibilidades para sua manifestação. Em um contexto alterado pelas medidas impostas pela pandemia da COVID-19, compreender como o lazer tem sido vivido se torna desafiador, tendo em vista as novas configurações de vida das pessoas, que foi modificada de forma inesperada e abrupta, promovendo um conjunto modificações na relação dos sujeitos com os espaços antes frequentados normalmente, com a própria casa, com o trabalho, com os afazeres cotidianos mais corriqueiros, assim como consigo mesmo e com seus pares. Refletir sobre o lazer como um fenômeno, que tem como uma de suas características a capacidade de potencializar sociabilidades (MATOS, 2001) por meio da interação com os outros, em uma realidade de distanciamento social, torna-se instigante, principalmente, ao se buscar entender como os discentes do Curso de Educação Física da UFPA,composto predominantemente de jovens como apontou o perfil dos partícipes desse estudo, estão vivenciando o lazer em tempos tão complexos e em uma fase da vida de intensas possibilidades de atividades em sociedade.

licere, Belo Horizonte, v.23, n.3, set/2020. 


\section{O Envolvimento dos Estudantes com o Lazer na Relação com as Obrigações, no Contexto de Distanciamento Social}

A cultura lúdica vivida no âmbito do lazer, hegemonicamente, se materializa na relação entre as pessoas e, fundamentalmente, mas não somente, nos espaços públicos, e estes dois aspectos nos foram tirados com a necessidade de distanciamento social. As relações de sociabilidades geradas pelos encontros proporcionam experiências valorativas na relação do sujeito consigo mesmo, com os lugares e com as outras pessoas, como uma tríade geradora de modos de viver, de ser e de interagir singulares às pessoas possibilitando a ampliação de saberes e práticas compartilhadas como produção cultural no fazer-se cidadãos(ãs).

Outros aspectos importantes para melhor compreensão dos dados que virão a seguir é a dimensão tempo aliada à falta de dinheiro. A Pesquisa sobre o Lazer do Brasileiro nos mostra que estes são os principais aspectos impeditivos para o usufruto do lazer do(a) brasileiro(a), isso está intimamente relacionado a forma como se configura a atual sociedade que tem o trabalho como a principal dimensão da vida humana, numa supervalorização deste, tendo em vista as sempre novas necessidades de consumo na relação com o surgimento acelerado de novas tecnologias e consequentemente o aumento da jornada de trabalho para a ampliação da remuneração que possibilitaria condições dignas de existência e a inserção nos novos padrões sociais anunciados diuturnamente pelo mercado (MAYOR; ISAYAMA, 2017).

Nessa perspectiva, compreender a relação do distanciamento social gerado pela pandemia da COVID-19, com as vivências de lazer na relação com as obrigações dos estudantes de Educação Física neste período é o principal interesse deste tópico. De modo que, ao perguntar aos discentes como eles avaliam o envolvimento com as vivências do lazer, considerando os meses de pico da pandemia no Estado do Pará (abril e maio) na 
Vivências do Lazer para Discentes do Curso de Educação Física da Universidade Federal do Pará no

comparação com os meses anteriores, dos 104 (100\%) estudantes que responderam (73)70,1\% disseram que diminuiu, (18)17,3\% disseram que aumentou e (10) $9,6 \%$ apontaram que não alterou, conforme ilustra o Gráfico 01:

Gráfico 1: Envolvimento dos estudantes com as vivências de lazer no período de distanciamento social.

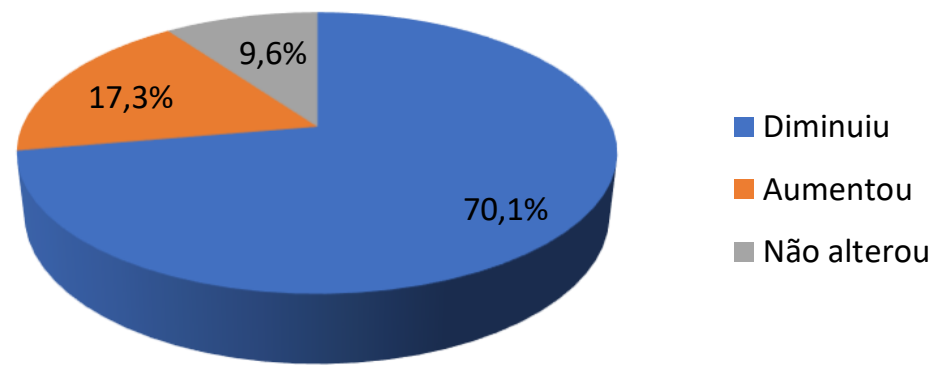

Fonte: Elaboração autoral.

A análise do grau de envolvimento ou não com as vivências de lazer por parte dos discentes do Curso de Educação Física da UFPA, nos meses de abril e maio, permitiu identificar que: (55)53\% avaliaram que diminuiu muito e (21)20,2\% avaliaram que diminuiu pouco; apenas (6) $6 \%$ disseram que aumentou muito e (12)11,5\% que aumentou pouco, e como já mencionado acima (10) 9,6\% disseram que não alterou, como expressa o gráfico 2:

licere, Belo Horizonte, v.23, n.3, set/2020. 


\section{Gráfico 2: Grau de envolvimento dos estudantes com as vivências de lazer no período de distanciamento social.}

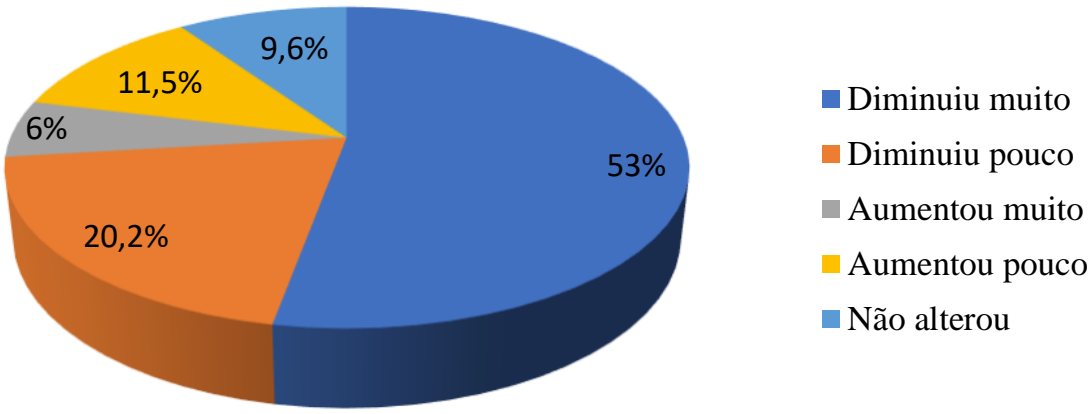

Fonte: Elaboração autoral.

Em se tratando de estudantes, na grande maioria jovens, apesar de muitos(as) ainda não estarem inseridos no mundo do trabalho e viverem um tempo completamente diferenciado, pelo fato de terem que ficar em isolamento social em suas casas, o fator tempo se revelou um aspecto importante, tendo em vista as dificuldades que alguns discentes tiveram para vivenciar o lazer. Esse aspecto pode se evidenciar quando os (as)estudantes revelaram as seguintes barreiras ${ }^{8}$ impeditivas e/ou limitadoras tais como: a)o trabalho (home office) (5)4,8\%;b)ajudar nas tarefas domésticas (7)6,7\% e; c) ajudar a cuidar de outras pessoas 4(3,8). Com relação à barreira de ordem emocionais/psicológicas esta afetou em média (43\%) dos discentes.

\footnotetext{
${ }^{8}$ As barreiras para o lazer não serão amplamente analisadas neste artigo, no entanto para melhor compreensão do grau de envolvimento dos estudantes com as vivências de lazer no período de distanciamento social será necessário alguns desses dados: Dentre as principais dificuldades encontradas relacionados aos fatores estruturais, humanos e tecnológicos para as vivências do lazer pelos(as) estudantes da FEF/ICED/UFPA foram citadas os problemas de ordem financeira 38(36,5\%); dificuldade no relacionamento familiar (19)18,3\%; falta de companhia $27(26 \%)$; falta de espaço na residência (25)24\%, falta de tempo devido aos trabalhos profissionais (homeoffice) (5)4,8\%; falta de tempo devido as atividades domésticas(7)6,7\%; falta de tempo por ter que cuidar de outras pessoas (filhos, irmãos, pais, avós...)(4)3,8\%; não aceitação da sua orientação sexual ou identidade de gênero 2(1,9); número grande de pessoas na residência 4(3,8\%); número insuficientes de aparelhos tecnológicos em relação ao número de pessoas (2)1,9\%; situação de violência familiar (1)1\%; não se aplica (31)29,8\%. Quanto aos principais fatores emocionais/psicológicos que limitaram ou impedem a vivência do lazer destacamos: a falta de vontade (46)44,2\%; alteração de humor (43)41,3\% e ansiedade (40)38,5\%.
}

licere, Belo Horizonte, v.23, n.3, set/2020. 
Dada as evidências é possível afirmar que a dificuldade financeira (38)36,5\%, a falta de companhia (27)26\%, a falta de espaço na residência (25)24\%, aliados às barreiras de ordem emocionais/psicológicas (média de 43\%)foram as principais barreiras encontradas para a vivência do lazer, o que nos leva a concluir que tais aspectos foram determinantes para que $73,1 \%$ dos interlocutores afirmassem que o lazer diminuiu no período de isolamento social.

A dificuldade financeira consiste em uma das barreiras mais recorrentemente mencionada, tendo em vista que, embora não seja fator determinante, a não disponibilidade de recursos financeiros distancia ou limita o acesso a alguns espaços, equipamentos e conteúdos do lazer em comparação com as pessoas economicamente mais favorecidas, promovendo o que Marcellino (2002) denomina de "barreiras intercalasses" Convém destacar que esse considerável percentual $(36,5 \%)$ dialoga com o que foi verificado na faixa salarial dos discentes do Curso de Educação Física, com mais da metade $(62,5 \%)$ declarando que a renda familiar se enquadra entre 1 e 3 salários mínimos.

No que diz respeito à falta de companhia como aspecto de diminuição do lazer, estudos já apontaram a sua relação com o acesso, a permanência e a desistência de determinada atividade. Ao realizar uma pesquisa com o público jovem Guedes et al. (2001) identificaram que os jovens consideram, como um fator essencial para aderência em uma prática de lazer a possibilidade de participação com seus pares. O estudo desenvolvido por Del Duca et al. (2014) identificou que homens e mulheres que possuíam parceiros (as) sentiam-se mais engajados em determinadas atividades pela possibilidade de vivência prazerosa e agradável de maneira conjunta. Nessa direção, pode-se destacar que a opção pela participação em atividades em grupo, turmas, pares, com o outro tem relação com a capacidade do lazer de promover vivências de socialização, liberdade, criação e experimentação de novas identidades (ROSA, 2006). 
Em relação à falta de espaço nas residências como condicionante que pode contribuir para a diminuição das vivências de lazer, pois apesar do lar ser considerado o equipamento de lazer mais acessível à população, as condições de moradia incidem no grau das atividades realizadas (MARCELLINO, 1996). Além do mais, cabe ressaltar também que o impacto do distanciamento social imposto pela pandemia da COVID-19 incidiu diretamente nos modos de morar, trabalhar e estudar, já que tais atividades acabam se entrelaçando, haja vista que as moradias se tornaram um espaço único para estudar, exercitar, descansar, distrair, entreter, trabalhar, etc., promovendo, em certos casos, uma significativa alteração na vida das pessoas, contribuindo com a “[...] extinção da dicotomia entre a jornada de trabalho versus horário de lazer ou descanso" (SILVEIRA et al., 2020, p. 3).

Por fim, destaca-se que fatores emocionais/psicológicos citados como barreiras impeditivas para a vivência do lazer, podem assim ser considerados, sobretudo, em tempos de pandemia da COVID-19, no qual o medo, os níveis de estresse e os sintomas da ansiedade podem aparecer em pessoas que, a princípio, eram saudáveis, bem como se intensificar naquelas que já possuíam algum histórico ou pré-disposição (FARO et al., 2020). Nesta perspectiva, ao se entender o lazer como uma escolha espontânea para ser vivida no tempo livre e os problemas relacionados à saúde mental como incapacitantes e desmotivadores, torna-se claro o quanto os abalos e desequilíbrios dessa ordem podem ser responsáveis pela diminuição das atividades de lazer.

Possivelmente, os(as) discentes que não tiveram suas vivências de lazer alteradas nesse período $10(9,6 \%)$ não foram tão impactados pelo contexto da pandemia da COVID19 e/ou por estarem acostumados com um lazer mais em casa, ou ainda pode estar relacionado ao fato de não terem vivenciado totalmente o distanciamento social. Os(As) estudantes que disseram que as vivências de lazer aumentaram(18)17,3\%, possivelmente 
são aqueles que de fato tiveram mais tempo e condições adequadas para vivenciarem o lazer durante a pandemia.

O contexto de distanciamento social impôs, para algumas pessoas, uma série de obrigações que nem sempre fizeram parte de suas rotinas diárias. Os sujeitos da pesquisa ao responderem quais as atividades obrigatórias foram realizadas em seus cotidianos no período de distanciamento social (a questão que poderiam marcar quantas opções quisessem), trouxeram a seguinte distribuição, com base no quantitativo de vezes que as respostas foram assinaladas: $26(12,2 \%)$ apontaram o trabalho (presencial ou home office), 82 (38,6\%) os afazeres domésticos, 46 (21,7\%) estudos e cursos (online), 29 $(13,6 \%)$ os cuidados com filhos e outros membros da família, 14 (6,6\%)os cuidados com pessoas doentes, $7(3,3 \%)$ os compromissos religiosos, $3(1,4 \%)$ os compromissos político social (reunião de partido político, entidade estudantil, associações etc.), 4 $(1,8 \%)$ indicaram o trabalho social (participação em campanhas e ações de ajuda ao próximo)e $1(0,4 \%)$ Outros, o qual revelou a ajuda nas compras da casa. Tais dados são expressos no gráfico 3: 


\title{
Gráfico 3: Atividades obrigatórias realizadas no período de distanciamento social.
}

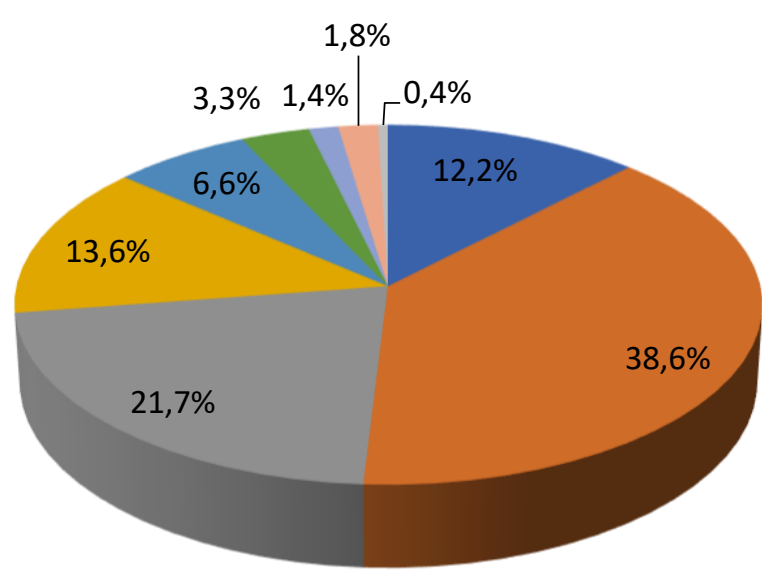

\author{
- Trabalho (presencial ou home \\ Office) \\ - Afazeres domésticos \\ Estudos e cursos (online) \\ Cuidado com os filhos e membros \\ da família \\ - Cuidados com pessoas doentes \\ Compromissos religiosos \\ Compromissos político sociais \\ - Trabalho social \\ $\square$ Outros
}

Fonte: Elaboração autoral.

Como se pode observar no Gráfico 3, o aspecto mais destacado pelos(as) estudantes como obrigação foram os afazeres domésticos, com percentual de quase $80 \%$. Importante para essa análise ressaltar que $74,4 \%$ dos sujeitos da pesquisa são do sexo masculino e apenas $25,6 \%$ são do sexo feminino.Faz-se também importante reforçar que $100 \%$ das pessoas do sexo feminino participantes da pesquisa destacaram os afazeres domésticos como atividade obrigatória,enquanto $25,6 \%$ de estudantes do sexo masculino não citaram os afazeres domésticos como obrigação.

Os percentuais acima mencionados remetem ao que se denomina de "relações sociais de sexo" (HIRATA; KERGOAT, 2007), isto é, evidencia um tipo de relação, recorrente entre os grupos de homens e de mulheres, na qual se estabelece uma divisão sexual do trabalho, determinando que esse ou aquele tipo específico de atividade laboral é pertencente ao masculino ou ao feminino. Esse tipo de divisão contribui para que se estabeleça uma relação desproporcional entre os sujeitos, marcada pela reprodução das 
desigualdades de papéis e funções sociais, bem como de estereótipos e preconceitos quando se subverte as regras sociais do trabalho.

A determinação do que seja trabalho de homens e de mulheres é uma construção histórica e social que se materializou, inclusive, na própria educação escolarizada, em que instituições educativas diferenciavam o ensino-aprendizagem para homens e mulheres, com base no que se considerava adequando ou inadequado para cada um deles (as), conforme as expectativas sociais de dado tempo (LOURO, 1997). Para as mulheres, ficou destinada a maternidade, o cuidar dos filhos, o recato, a submissão, as tarefas do lar, a permanência no ambiente doméstico; já aos homens coube a atuação no espaço público, no mundo do trabalho, no provimento financeiro do lar e tantas outras liberdades para além do âmbito doméstico (ALMEIDA, 2006).

A pesquisa de Sousa e Guedes (2016), que trata da desigual divisão sexual do trabalho doméstico no Brasil na última década, mostrou que em todas as regiões do país o percentual de mulheres que realizam afazeres domésticos corresponde a quase ou mais do que 90\%; já o percentual dos homens não passa de 60\%. Por região,no Norte, o envolvimento com o trabalho doméstico corresponde, respectivamente, a 91,5\% e 51,8\%, para mulheres e homens.

Quanto ao quantitativo de horas de realização dos afazeres domésticos, em pesquisa do IBGE, do ano de 2019, tal desigualdade também se apresenta, pois se identificou que as mulheres passam, aproximadamente, 18,5 horas por semana nas atividades domésticas; enquanto que os homens se ocupam apenas de 10,3 horas para o mesmo fim (IBGE, 2019). Estima-se que em tempos de distanciamento social pela COVID-19, a rotina laboral das mulheres tenha se intensificado, consideravelmente, por conta das demandas estarem concentradas, predominantemente, no espaço doméstico, contribuindo para 
aumentar situações de vulnerabilidade e impactos na saúde de muitas mulheres em função da sobrecarga de trabalho (MORAES, 2020).

Embora os(as) estudantes estejam sem aulas, tendo em vista que, como já mencionamos, a Universidade Federal do Pará teve suas atividades de ensino suspensas, mesmo assim, um percentual de 44,2\% informou que se dedicaram a estudos e cursos online. É possível constatar que, com a necessidade de distanciamento social no Brasil, uma quantidade expressiva de cursos gratuitos e pagos estão sendo ofertados por diversificadas instituições e universidades, inclusive a UFPA, como parte de suas ações extensionistas, além das palestras e debates temáticos (lives) promovidas por grupos de pesquisa, cursos, entidades sociais, entre outras instituições.

Apesar de os sujeitos da pesquisa serem estudantes universitários $26(12,2 \%)$ apontaram como obrigação o trabalho (presencial ou home office).A relações entre lazer e trabalho e outras obrigações são temas de pesquisa de diversos autores e a predominância de análise na produção acadêmica destes apontam para a influência dialética nessa relação (DUMAZEDIER, 1980; MARCELLINO, 2007).

Segundo Gomes (2014), são cada vez mais tênues e difusos os limites entre essas duas esferas da vida humana, lazer e trabalho, isso se dá como consequência do processo de flexibilização do trabalho, a divisão internacional do trabalho e, cada vez mais, o avanço tecnológico. Diante de tais fatores a autora aponta a existência de relações dialógicas e múltiplas entre lazer e trabalho e critica as análises que relacionam o lazer, levando em consideração apenas o trabalho produtivo.

Numa sociedade como a que vivemos, na qual a produção e o consumo são aspectos destacados, a ocupação é vista como algo que identifica o sujeito e sem o qual sua identidade entra em crise (ROSA; SILVA, 2017). O lazer é visto como um tempo e espaço oportuno para vivenciar atividades que proporcionam prazer (MELO, 2003), participação 
cultural (MARCELLINO, 2007), desenvolvimento pessoal e social (DUMAZEDIER, 1979). Embora, o lazer seja entendido também como uma necessidade humana (GOMES, 2014), nem sempre ele é valorizado suficientemente para estar em destaque em termos de políticas públicas ou mesmo nas vidas das pessoas.No entanto, a pandemia e a consequente necessidade de distanciamento social,tem mostrado o quanto as diversificadas práticas culturais do lazer (atividade física e artísticas, trabalhos manuais etc.) são importantes como afirmação de nossa condição humana.

Cuidar,na atual conjuntura que vivemos, tem sido para muitos, um grande processo de aprendizado, cuidar de si não numa perspectiva egoísta ou por mero interesse individual, mas como desenvolvimento pessoal, pois quem cuida profundamente de si mesmo, está muito mais próximo para lidar com o outro, e ao cuidar do outro testamos a potência e também os limites de nossas práticas e, assim, aprendemos a necessidade de respeitar o outro como alguém diferente de si próprio. Como afirma Méllo, (2019, p. 236) “cuidado, em saúde, é favorecer uma vida mais fluida para todos e cada um [...]". Nessa perspectiva, a pesquisa revelou que 13,6 \%dos(as) estudantes, nesse processo de distanciamento social, dedicou-se, como obrigação,da ação de cuidar dos membros da família e 6,6\% tiveram a necessidade de cuidar de pessoas que adoeceram. Nessa mesma direção, mas ainda um percentual pequeno, 1,8\% dos estudantes indicou o trabalho social(participação em campanhas e ações de ajuda ao próximo) também, como uma forma de cuidar, neste caso cuidar de quem, possivelmente, nem se conhece, mas que nos solidarizamos por entender a importância de todos e cada um diante da Pandemia que vem matando milhares de pessoas no Brasil e no mundo.

Os dados mostram ainda, que há um baixo percentual de estudantes envolvidos em ações políticas $(1,4 \%)$ e em trabalhos sociais $(1,8 \%)$, como afirma Stoppa (2017), as restrições da vida cotidiana, muitas vezes acabam por dificultar as oportunidades de 
Vivências do Lazer para Discentes do Curso de Educação Física da Universidade Federal do Pará no

Contexto de Pandemia da Covid - 19

Lucília da Silva Matos; Welington da Costa Pinheiro e Mirleide Chaar Bahia

desenvolvimento da politização dos indivíduos, nessa perspectiva afirma que o processo de conscientização, mobilização e participação política das pessoas não se dá de forma automática.

Em um estudo sobre a participação de discentes da Universidade de Brasília (UNB) na política, Messenberg (2015) identificou que $87 \%$ dos discentes,de um total de 94 , declararam não participar de nenhuma associação, conselho, sindicato ou movimento social (aproximando-se do baixo percentual de envolvimento, 1,4\%, apresentado pelos discentes de Educação Física da UFPA), tendo como principais motivos a falta interesse nas atividades políticas nas instituições que fazem parte do seu universo, a falta de tempo para o exercício de tais atividades e a pouca identificação com grupos políticos. Tais fatores podem ter relação direta com a própria realidade da política nos últimos anos, marcada pela"[...] falta de credibilidade da política nacional aliada ao sentimento de indignação frente à forma pouco transparente, e muitas vezes corrupta, com o trato da coisa pública no Brasil [...]” (MESSENBERG, 2015, p. 13).

Ao realizar um estudo acerca da participação política dos jovens na atualidade, Gohn (2018), mesmo reconhecendo que a imagem desgastada das instituições públicas, as desilusões partidárias e a estrutura política brasileira deficiente sejam aspectos que diminuem o interesse, o que mais caracteriza a relação jovem e política é a nova cultura de participação desse público,que vem se configurando na última década, evidenciando que a participação em movimentos e coletivos de jovens é diferente em comparação a momentos políticos anteriores. Hoje,essa atuação é diferente, inclusive por conta da utilização das tecnologias, bem como dividida e heterogênea,uns "[...] adotam práticas democráticas e tentam pautar novos direitos sociais (passe livre, por exemplo); outros tencionam e enfraquecem a democracia, ao questionar direitos, como projetos do tipo “Escola sem Partido" e outros (GOHN, 2018, p.130).

licere, Belo Horizonte, v.23, n.3, set/2020. 
E por fim, 3,3\% dos estudantes registraram o seu compromisso religioso. $\mathrm{Na}$ atualidade, a espiritualidade e a religiosidade se tornaram um meio de enfretamento da crise sanitária da COVID-19, agindo como um recurso evidencia e mobiliza a transcendência humana (PORRECA, 2020). Dessa maneira, acabam mais do que nunca assumindo considerável papel na vida das pessoas, apontando para o sentido de esperança, o poder da resiliência, a reflexão sobre uma possível testagem positiva para a doença e no seu enfrentamento, bem como com“[...] a percepção de reencontro das relações interpessoais - família e outros, o reconhecimento da fragilidade e vulnerabilidade individual e coletiva, a reaproximação de culturas, crenças e da própria religião (TAVARES, 2020, p. 3).

A partir da reflexão sobre o envolvimento ou não nas vivências, as atividades obrigatórias e as barreiras para o lazer enfrentadas em tempos de distanciamento social em decorrência da COVID-19, fica explícito que o lazer não é um ente abstrato e alheio à realidade acontecendo em dado tempo e espaço, haja vista que ele se relaciona com as diversas formas que temos de ocupação do tempo, ao mesmo passo que se inter-relaciona e sofre a ação de diversos condicionantes nesse processo.

\section{Principais Interesses do Lazer Dds Estudantes Durante a Pandemia}

O entendimento do lazer enquanto um fenômeno social, necessário à vida humana, presente nas experiências individuais e coletivas de homens e mulheres foi fundamental no processo de disputa para a consolidação deste em forma de lei como direito social na constituição cidadã de 1988. Desde então, vemos, ainda de maneira muito tímida, o lazer ser pauta no processo de formulação de políticas públicas que dêem conta dessa expectativa social. Por outro lado, a indústria do entretenimento, "responsável por geração de empregos e movimentadora de somas exorbitantes na economia mundial" 
Vivências do Lazer para Discentes do Curso de Educação Física da Universidade Federal do Pará no

Contexto de Pandemia da Covid - 19

Lucília da Silva Matos; Welington da Costa Pinheiro e Mirleide Chaar Bahia

(SILVA, 2017, p.1), segue atenta para o campo do lazer se tornando um mercado ainda mais forte com a expansão dos meios digitais, uso de novas tecnologias e com a criação de novos produtos e serviços na tentativa de alcançar as expectativas dos consumidores e com isso gerar cada vez mais lucros.

Se por um lado o isolamento social vem afetando alguns setores do lazer e entretenimento, principalmente aqueles que comumente as pessoas recorriam para se divertir, como parques, cinema, teatros, bares, shows presenciais ${ }^{9}$, por outro o entretenimento online passou a ser uma das formas de consumo de conteúdos e de lazer bastante usado. Nessa perspectiva além dos meios mais tradicionais, como a TV aberta e a fechada, games e plataformas de streaming crescem $^{10}$.

Tal realidade pode ser vista na Tabela $2^{11}$, a seguir, que detalha os percentuais das atividades de lazer vivenciadas durante o distanciamento social, na qual podemos evidenciar que o assistir séries foi a segunda atividade mais citadas dos estudantes com (80)76,9\% de frequência, apenas sendo menor do que o "bater papo por WhatsApp" com (89) $85,6 \%$ de uso pelos estudantes.

Tabela 2: Atividades de lazer vivenciadas por estudantes de Educação Física durante o período de distanciamento social (meses de abril e maio), devido a Pandemia da COVID 19.

\begin{tabular}{l|l|l}
\multicolumn{1}{c|}{ Atividades } & $\mathbf{N}^{\circ}$ & $(\%)$ \\
\hline Assistir série & 80 & $76,9 \%$ \\
\hline Assistir shows na Tv aberta e ou online, & 35 & $33,7 \%$ \\
\hline Assistir TV aberta & 66 & $63,5 \%$ \\
\hline Assistir TV fechada & 20 & $19,2 \%$ \\
\hline
\end{tabular}

\footnotetext{
9"Segundo a Associação Brasileira dos promotores de eventos - ABRAPE, 51,9\% dos eventos programados - cerca de 300 mil para 2020 - foram cancelados, adiados ou estão em situação incerta, o que representará uma perda de RS 90 bilhões na indústria como um todo e uma demissão de aproximadamente 580 mil pessoas". Disponível em: http://br.jetss.com/noticias/brasil/2020/04/pesquisa-aponta-risco-de-colapso-nosetor-de-cultura-e-entretenimento-no-pais/. Acesso em: 01 ago. 2020.

${ }^{10}$ Ver matéria "A expansão do streaming e da indústria do entretenimento em meio a pandemia". Disponível em: https://tiinside.com.br/28/05/2020/a-expansao-do-streaming-e-da-industria-do-entretenimento-emmeio-a-pandemia/. Acesso em: 01 ago.2020.

${ }^{11}$ Importante salientar que a questão foi formulada dando ao máximo de opções de lazer que poderiam ser vivenciadas em casa, mas trazendo de forma ampla os diversificados interesses do lazer Dumazedier (1979), que são classificados de acordo com o interesse principal do sujeito: físicos, artísticos, manuais, intelectuais e sociais. Além destes, a literatura científica aponta outros, como os interesses turísticos (CAMARGO, 1986) e virtuais (SCHWARTZ, 2003) e ainda deixamos a opção de outros, no qual o estudante poderia escrever outro tipo de atividade que não estivesse como um item a ser marcado.
}

licere, Belo Horizonte, v.23, n.3, set/2020. 
Vivências do Lazer para Discentes do Curso de Educação Física da Universidade Federal do Pará no

Contexto de Pandemia da Covid - 19

Lucília da Silva Matos; Welington da Costa Pinheiro e Mirleide Chaar Bahia

\begin{tabular}{l|c|c}
\hline Bater papo por WhatsApp & 89 & $85,6 \%$ \\
\hline Brincar com os filhos e ou outros membros da família & 27 & $26 \%$ \\
\hline Comunicações por Facebok & 60 & $57,7 \%$ \\
\hline Comunicações por Instagram & 72 & $69,2 \%$ \\
\hline Comunicação por Twitter & 34 & $32,7 \%$ \\
\hline Cozinhar por lazer & 32 & $30,8 \%$ \\
\hline Cuidar de plantas por lazer & 11 & $10,6 \%$ \\
\hline Desenhar & 8 & $7,7 \%$ \\
\hline Dormir durante o dia & 44 & 42,3 \\
\hline Fazer artesanato & 9 & $8,7 \%$ \\
\hline Fazer cursos online de temas do seu interesse & 38 & $36,5 \%$ \\
\hline Jogar jogos de cartas & 24 & $23,1 \%$ \\
\hline Jogar jogo de tabuleiro & 17 & 16,3 \\
\hline Jogar videogame ou jogos do celular & 47 & $45,2 \%$ \\
\hline Ler livros (impresso ou online) & 56 & $53,8 \%$ \\
\hline Ouvir música & 78 & $75 \%$ \\
\hline Participar de aniversários, encontros sociais online & 14 & 13,5 \\
\hline Participar ou assistir lives & 56 & 53,8 \\
\hline Pintar & 8 & 7,7 \\
\hline Praticar atividade física & 59 & 56,7 \\
\hline Praticar esporte & 18 & $17,3 \%$ \\
\hline Visitar museus (online) & 3 & 2,9 \\
\hline Visitar pontos turísticos & 3 & 2,9 \\
\hline Outros(Criação áudio visual) & 1 & $1 \%$ \\
\hline Fonte: Pesquisa autoral & & \\
\hline
\end{tabular}

Fonte: Pesquisa autoral.

Esse percentual expressivo das séries está relacionado também com a popularização da internet, que gradativamente vem mudando a forma de consumir séries e filmes, linguagens presentes tanto em TV aberta e fechadas quanto em plataformas de streaming na qual é possível também ouvir literatura nas plataformas especializadas em audiolivros e ouvir música, está última citada por (78)75\% dos estudantes.

Segundo a matéria "A expansão do streaming e da indústria do entretenimento em meio a pandemia," anteriormente citada, no Brasil 50\% dos usuários de internet estão buscando esses serviços que com diferenciações podem ser gratuitos ou pagos.

O processo de popularização da internet e o uso de aplicativos de comunicação nos celulares, tablets ou computadores facilitaram a comunicação virtual, no caso do celular muito mais, uma vez que este aparelho, pelo seu tamanho e praticidade, pode ser levado para todos os lugares, aspecto que pode ser o principal responsável pelo expressivo uso entre estudantes com (89)85,6\% de adesão ao uso de WhatsApp para "bater papo", (72) 
Vivências do Lazer para Discentes do Curso de Educação Física da Universidade Federal do Pará no Contexto de Pandemia da Covid - 19

Lucília da Silva Matos; Welington da Costa Pinheiro e Mirleide Chaar Bahia

69,2\% ao Instagram, (60)57,7\% ao facebok e (34)32,7\% ao twitter e também responsável por todas as outras vivências online citadas pelos estudantes presentes na Tabela 02.

Participar e/ou assistir lives foi citado por (56) 53,8 dos estudantes e assistir shows pela TV ou online por (35)33,7. Com a ampliação de lives na internet esse processo vem se aperfeiçoando na pandemia, de modo que um dos shows alcançou um recorde mundial com mais de 3,2 milhões de pessoas conectadas simultaneamente no YouTube e os canais de TV fechada passaram a exibir lives como One World: Togetherat home. Com essa adesão expressiva, diversificadas marcas passaram a apoiar outras lives de $\operatorname{artistas}^{12}$. No Instagram e facebook há diariamente transmissões ao vivo para os mais diferentes gostos. No entanto o acesso à internet também se configura como uma barreira para alguns estudantes, isto porque $25,2 \%$ dos estudantes não têm acesso a internet wi-fi, em suas casas e mesmo os que tem, nem sempre a qualidade/potência da internet é suficiente para determinados acessos.

O interesse social do lazer, presente em praticamente todas as vivências, mas ressaltado na necessidade de se encontrar, ver, conviver com o(a) outro(a), conversar e/ou festejar, realizar trocas afetivas faz parte da condição humana como seres gregários que somos, os nossos ancestrais já se reuniam em torno da fogueira para repartir o alimento. Antes da pandemia além de receber pessoas em casa, nos encontrávamos com amigos e familiares em espaços públicos (parques, praças, ruas etc.) e ou semipúblicos (bares, restaurantes etc.). Nessa perspectiva, as atividades de encontros online, não substituíram esse que é o principal conteúdo do lazer do brasileiro, o social, mas amenizou essa falta e popularizou muito mais as práticas online. Na pesquisa Lazer no Brasil, (STOPPA; ISAYAMA, 2017), os dados evidenciam que as atividades de lazer mais vivenciadas no

12 Ver matéria "A expansão do streaming e da indústria do entretenimento em meio a pandemia". Disponível em: https://tiinside.com.br/28/05/2020/a-expansao-do-streaming-e-da-industria-doentretenimento-em-meio-a-pandemia/. Acesso em: 01 ago. 2020.

licere, Belo Horizonte, v.23, n.3, set/2020. 
fim de semana entre as mulheres são as sociais, que é a segunda mais vivenciadas por homens também, a primeira são as esportivas.

Nem somente de atividades online se vive na quarentena, praticar atividades físicas é uma atividade vivenciada por (59)56,7\% dos estudantes enquanto as vivências esportivas (18)17,3\%, brincar com os filhos e outros membros da família (27) 26\%, Jogar cartas (24) 23,1\%, Jogos de tabuleiro (17) $16,3 \%$.

Atividade como cozinhar, (32)30,8\% para muitos foi uma grande descoberta durante o período de distanciamento social, assim como o cuidar de plantas (11) 10,6\% e ou fazer artesanato (9) 8,7\%.Essas atividades, que estão no rol dos chamados interesses manuais (DUMAZEDIER, 1979) na pesquisa sobre o lazer do brasileiro apresentou dados ainda mais baixos, segundo Mayor e Isayama (2017) isso se dá, possivelmente, por não cumprirem de forma pragmática às exigências do atual mercado de trabalho, pelo pouco incentivo no âmbito educacional e ainda pode estar relacionado a pouca sensibilidade a multiplicidade de experiências humanas.

A sesta (cochilo após o almoço) sempre foi uma vivência muito comum na vida dos paraenses, possivelmente o clima muito quente da região, aliado a cultura de se tomar açaí com farinha de mandioca, principalmente no almoço, são aspectos convidativos ao descanso. No entanto, com uma sociedade ainda muito voltada a moral da produtividade, o mundo acelerado, as muitas tarefas que passam a fazer parte da realidade dos estudantes universitários, essa prática nem sempre é possível. Com o distanciamento social (44)42,3\% conseguiram se reencontrar com o direito ao descanso, no caso específico dormir durante o dia.

O percentual de estudantes (56)53,8\% que apontaram a leitura e os cursos online (38)36,5\%como uma das vivências de lazer foi bastante surpreendente em comparação com outras pesquisas realizadas (STOPPA; ISAYAMA, 2017; MATOS et al., 2018), 
possivelmente isso se dá por se tratar de jovens universitários que convivem com tal prática permanentemente, mas também pode estar relacionado com certa popularização do acesso online aos livros e cursos nesse período.

Como ressalta Melo (2007) faz-se necessário pensarmos uma "alfabetização cultural em várias vias" como forma de intensificar outras dimensões humanas e estimular às pessoas, de forma consciente, a exercitarem o seu direito de escolher as múltiplas possibilidades de produção cultural.

\section{Novas e Adaptadas Atividades de Lazer no Período de Distanciamento Social}

Le Breton (2019), no livro Antropologia das Emoções, ao tratar do corpo e da simbologia social toma alguns casos de crianças que por circunstâncias vividas estiveram isoladas por muito tempo do convívio social entre seres humanos, as chamadas "crianças selvagens", sua análise reafirma a tese de que "o homem só realiza-se na cultura que o acolhe” (p.16) e que as nossas mais íntimas sensações, as mais intangíveis, os nossos gestos mais elementares, a forma do nosso corpo, e as formas de convivências provêm do meio social e cultural em que vivemos, pois cada pessoa é um gerador de sociabilidade para o outro, dessa forma, a simbologia corporal é como memória que deve ser minuciosamente cultivada e sempre "alimentada no espelho do comportamento e das palavras dos outros" (p.42).

Nesse sentido, o autor enfatiza o quanto chega a ser assustador o poder de adaptação dos seres humanos, mesmo em situações extremas, que submetidos ao isolamento durador, recriam sua experiência do mundo. Embora, Le Breton tenha tomado alguns casos de isolamento extremo, ele nos faz pensar, como seres culturais que somos, acerca das possíveis mudanças em nossas práticas de sociabilidade, como os impactados 
decorrentes da necessidade de distanciamento social provocado pela Pandemia do Coronavírus (COVID-19).

Outro aspecto importante que esse tema nos faz refletir é, por outro lado, a dificuldade que temos no que tange a necessidade de realizarmos mudanças, quais quer que sejam.

Quanto à questão se os(as) discentes criaram ou adaptaram alguma atividade de lazer durante o período mais intenso de distanciamento social no Pará (abril e maio) 74\% responderam que não criaram ou adaptaram atividades de lazer e $26 \%$ disseram que sim.

\section{Gráfico 4: Atividades obrigatórias realizadas no período de distanciamento social.}

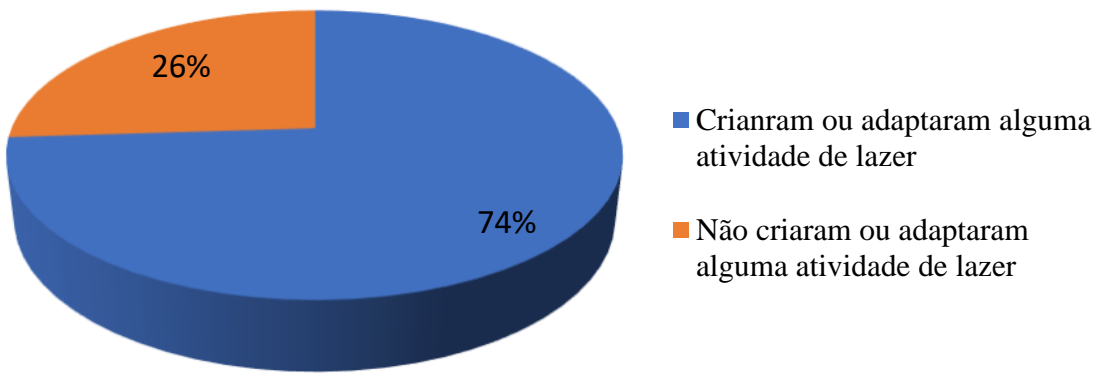

Fonte: Pesquisa autoral.

O consideravel percentual $(74 \%)$ de discentes que declarou não tercriado ou adaptado nenhuma atividade de lazer durante o período de distanciamento social permite elaborar algumas reflexões. Podemos inferir que esse quantitativo tenha relação com olhar atribuído ao lazer que o restringe restrito ou limitado a um conjunto de formas mais convencionais de vivê-lo, não o concebendo como uma manifestação permeada pela criatividade e liberdade (WERNECK, 2000), o que não contribui para que o lazer promova a ampliação da experiência singular de descoberta subjetiva do prazer como princípio transformador da vida (MELO, 2006). Por outro lado, os fatores condicionantes para vivência do lazer (atitude, interesse, disposição, saúde, entre outros) também devem 
ser levando em consideração, sobretudo, quando se ressalta os impactos de uma pandemia na vida das pessoas e as dificuldades por ela ocasionadas para a realização de vivências de toda ordem.

Em relação aos vinte e seis (26) discentes que criaram ou adaptaram atividades de lazer, 24 especificaram suas adaptações e/ou criações. As vivências mais adaptadas foram as atividades físicas (citadas por $62,5 \%$ dos(as) discentes) que passaram a serem realizadas no ambiente da casa, tendo que se encaixar de acordo com o tamanho e organização do ambiente, conforme segue alguns relatos escritos pelos estudantes:

Atividades físicas, principalmente. Adaptei alguns exercícios para fazer dentro de casa, como a corrida, aqui em casa tem espaço, dá para correr mesmo que ao lado dos móveis, e depois eu subia a escada e corria pelo segundo andar. Adaptei essa atividade no intuito de movimentar o corpo durante a pandemia, além de tentar manter a forma (DISCENTE1).

Adaptei meus exercícios físicos, para que pudesse fazer em um espaço menos, no caso, meu quarto (DISCENTE 21).

Outro aspecto citado por 33,3\% dos 24 estudantes foi a adaptação dos próprios exercícios e ou equipamentos:

Adaptei o exercício físico que antes era feito somente na academia, utilizando alguns materiais específicos e outros adaptados (garrafas, cabo de vassoura, mochila com livros etc. (DISCENTE 2).

Prática de exercícios físicos com objetos de casa (DISCENTE 3).

Treinos de musculação, funcionais utilizando materiais de casa, pesos, para desenvolver atividades (DISCENTE 22).

Outro aspecto que chama muito atenção nesses tempos de distanciamento social é a necessidade de se comunicar, conversar, jogar, assistir filmes e se encontrar mesmo que de forma online com amigos e familiares. Com relação a esse aspecto $17 \%$ dos(as) discentes que especificaram suas criações ou adaptações fizeram menção a essa perspectiva. Como ressalta Eduardo Galeano no O livro dos abraços, “[...] Quando é verdadeira, quando nasce da necessidade de dizer, a voz humana não encontra quem a detenha. Se lhe negam a boca, ela fala pelas mãos, ou pelos olhos, ou pelos poros, ou

licere, Belo Horizonte, v.23, n.3, set/2020. 
por onde for [...]" (GALEANO, 2009, p.23). Seguem alguns desses depoimentos escritos pelos estudantes:

Assistir filme com os amigos ao mesmo tempo online pelo app rave, e jogar o jogo ludo de tabuleiro (DISCENTE 4).

Encontro com os amigos via WhatsApp e vídeo chamada (DISCENTE 8).

Jogos de tabuleiro que jogava com os amigos, foram feitos por meios digitais (DISCENTE 9).

Além dessas atividades já citadas, a leitura, a escrita, o desenho e o ato de cozinhar também foram citadas como atividades que tiveram que ser adaptadas ou criadas, o que nos faz supor que foram despertadas ou aperfeiçoadas neste tempo de distanciamento social.

A escrita, leitura e o desenho se tornaram mais presentes no dia a dia, já que as atividades fora de casa estavam suspensas, mais tempo para se dedicar às atividades que requerem concentração (DISCENTE 21).

A criação ou adaptação das atividades de lazer mencionadas pelos discentes do curso de Educação Física da UFPA que participaram da pesquisa revelam o potencial livre e criativo do lazer, principalmente, quando concebido como uma oportunidade, um espaço, uma experiência, uma "[...] vivência de valores, percepções e sensibilidades, aspectos que contribuem para mudanças de ordem subjetiva e cultural [...]" (MATOS et al., 2018, p. 48). Dessa maneira, podemos entender que as atividades realizadas trouxeram contribuições individuais e coletivas, bem como novos olhares, aprendizagens e aprendizagens por meio do lazer, mesmo em um contexto tão peculiar de distanciamento social. Isso somente é possível, como bem diz Marcellino (2008), o lazer é capaz de formar valores, condutas, atitudes, assim como novas formas de interação individuais, com os outros e com o mundo. 


\section{Considerações Finais}

Nesse artigo situamos o lazer como uma necessidade humana e uma dimensão da cultura, que se manifesta na sua relação com as outras dimensões da vida e que tem como uma de suas principais características a capacidade de potencializar a sociabilidade por meio das interações com as outras pessoas, os espaços e as produções culturais.

A análise das vivências do lazer de discentes de Educação Física da Universidade Federal do Pará permitiu refletir que envolvimento ou não nas vivências, as atividades obrigatórias e as barreiras para o lazer enfrentadas em tempos de distanciamento social, em decorrência da COVID-19, explicitam que o lazer não é um ente abstrato e alheio à realidade que acontece em dado tempo e espaço, haja vista que ele se relaciona com as diversas formas que temos de ocupação do tempo e com os aspectos que condicionam a sua vivência.

A partir da análise das vivências do lazer dos discentes ficou evidente que se por um lado o isolamento social vem afetando alguns setores do lazer e entretenimento, principalmente, aqueles que comumente as pessoas recorriam para se divertir, como parques, cinema, teatros, bares, shows presenciais; por outro o entretenimento online passou a ser uma das formas de consumo de conteúdos e de lazer bastante usado.

Em relação aos principais fatores analisados para um percentual expressivo dos discentes que responderam que não criaram ou adaptaram as vivências de lazer foram, inferimos que olhar limitado pelas atividades mais convencionais de vivencias, além dos condicionantes próprios do período de distanciamento social, tais como a atitude, o interesse, a disposição e a saúde. Por outro lado, as atividades mais adaptadas foram as atividades físicas que passaram a serem realizadas no ambiente da casa, tendo que se encaixar de acordo com o tamanho e organização do ambiente, bem como passar por adaptação dos próprios exercícios criando ou adaptando equipamentos para esse fim. 
Além das novas formas de comunicação a fim de estar "junto" com o outro online, seja para conversar, jogar, ou assistir filmes.

Nessa perspectiva concluímos que as atividades de lazer foram fundamentais no sentido de fortalecimento da vida e que estas trouxeram contribuições individuais e coletivas além de novos olhares e aprendizados por meio do lazer no contexto de distanciamento social.

\section{REFERÊNCIAS}

ABREU JUNIOR, José Maria de Castro. O vírus e a cidade: Rastros da gripe espanhola no cotidiano da cidade de Belém (1918). Belém: Paka-Tatu, 2018.

ALMEIDA, Jane Soares. Mulheres na educação: missão, vocação e destino? A feminização do magistério ao longo do século XX. In: SAVIANI, Demerval, et al. (org). O Legado educacional do século XX no Brasil. São Paulo: Autores Associados, 2006.

BAHIA, Mirleide Chaar. O lazer e as relações socioambientais em Belém, Pará. Belém: NAEA, 2014.

BEZERRA, Anselmo César Vasconcelos; SILVA, Carlos Eduardo Menezes da; SOARES, Fernando Ramalho Gameleira e SILVA, José Alexandre Menezes da. Fatores associados ao comportamento da população durante o isolamento social na pandemia de COVID-19. Ciênc. saúde coletiva [online]. 2020, v.25, suppl.1 [citado 2020-0809],p.2411-2421.

em: http://www.scielo.br/scielo.php?script=sci_arttext\&pid=S141381232020006702411\&ln $\mathrm{g}=$ pt\&nrm=iso. Acesso em: 02 ago. 2020.

BRASIL. MINISTÉRIO DA SAÚDE. Coronavírus. Disponível em: http://covid.saude.gov.br/. Acesso em: 07 ago. 2020.

CAMARGO, Luiz Octávio de Lima. O que é lazer? São Paulo: Perspectiva, 1986.

CONSÓRCIO DE IMPRENSA COVID-19. Dados diários. Disponível em: http://g1.globo.com/bemestar/coronavirus/noticia/2020/08/07/casosmortesporcoronavir us-no-brasil-em-7-de-agosto-segundo-consorcio-de-veiculos-deimprensa.ghtml. Acesso em: 07 ago. 2020.

DEL DUCA, G. F.; NAHAS, M. V.; HALLAL, P. C.; PERES, K. G. Atividades físicas no lazer entre adultos de Florianópolis, Santa Catarina, Brasil: estudo populacional sobre as características das práticas e de seus praticantes, Ciência \& Saúde Coletiva,v. 19, n. 11, p. 4595-4604, nov. 2014. Disponível em: http://www.scielo.br/pdf/csc/v19n11/1413-8123-csc-19-11-4595.pdf. Acesso em: 02 jul. 2020.

licere, Belo Horizonte, v.23, n.3, set/2020. 
DEL PRIORE, Mary. História da gente brasileira, República- Memórias (1889-1950). Rio de Janeiro: Le Ya, 2017.

DINO, Flávio. Coronavírus e fascismo: patologias que desafiam o brasil. In: TOSTES, Anjuli e FILHO, Hugo Melo (Org.) Quarentena: reflexões sobre a pandemia e depois. Bauru: Editora Canal 6, 2020.

DUMAZEDIER, Jofre. Sociologia empírica do lazer. São Paulo, Perspectiva.1979.

Valores e conteúdos culturais do lazer. São Paulo: Sesc, 1980.

FARO, André et al. COVID-19 e saúde mental: a emergência do cuidado. Estud. psicol. (Campinas), Campinas, $\quad$ v. $\quad 37, \quad$ e200074, 2020. https://doi.org/10.1590/1982$0275202037 \mathrm{e} 200074$. Available from https://www.scielo.br/scielo.php?script=sci_arttext\&pid=S0103166X2020000100507\&lng=en\&nrm=iso. access on 16 Sept. 2020. Epub June 01, 2020.

GALEANO, Eduardo. O livro dos abraços. Tradução de Eic Nepomuceno. 2. ed. Porto Alegre: L\&PM, 2009, p. 23.

GIL, A. C. Métodos e técnicas de pesquisa social. 5. ed, São Paulo: Atlas, 1999.

GOHN, Maria da Glória. Jovens na política na atualidade - uma nova cultura de participação. Cad. CRH, Salvador, v. 31, n. 82, p. 117-133, abr. 2018. Disponível em: https://www.scielo.br/scielo.php?script=sci_arttext\&pid=S01034979201

000100117\&lng=pt\&nrm=isso. Acesso em: 09 ago. 2020.

GOMES, Christianne Luce. Lazer: necessidade humana e dimensão da cultura. Revista Brasileira de Estudos do Lazer. Belo Horizonte, v. 1, n.1, p.3-20, jan./abr. 2014. Disponível em: http://periodicos.ufmg.br/index.php/rbel/article/view/430. Acesso em: 04 mai. 2020.

GUEDES, Dartagnan Pinto et al. Níveis de prática de atividade física habitual em adolescentes. RevBrasMedEsporte, Niterói , v. 7, n. 6, p. 187-199, Dec. 2001 - Disponível: http://www.scielo.br/scielo.php?script=sci_arttext\&pid=S151786922001000600002\&lng=en\&nrm=iso. Acesso em: 09 ago. 2020.

HIRATA, Helena; KERGOAT, Danièle. Novas configurações da divisão sexual do trabalho. Cafajeste. Pesqui. São Paulo, v. 37, n. 132, p. 595-609, dezembro de 2007. Disponível em: http://www.scielo.br/scielo.php?script=sci_arttext\&pid=S010015742007000300005\&lng=en\&nrm=iso. Acesso em: 09 ago. 2020.

INSTITUTO BRASILEIRO DE GEOGRAFIA E ESTATÍSTICA. Disponível em: http://www.ibge.gov.br/. Acesso em: 08 ago 2020.

. Pesquisa Nacional por Amostra de Domicílios Contínua, 2019. Disponível em: http://www.ibge.gov.br/. Acesso em: 08 ago. 2020

KOLATA, Gina. Gripe: a história da pandemia de 1918. Rio de Janeiro: Record, 2002.

LE BRETON, David. Antropologia das Emoções. Petrópolis: Editora Vozes, 2019.

licere, Belo Horizonte, v.23, n.3, set/2020. 
LOURO, Guacira. Gênero e magistério: identidade, história e representação. In: CATTANI, Denise et al. (Org.). Docência, memória e gênero. Estudos sobre formação. São Paulo: Escrituras, 1997, p. 123-135

MARCELLINO, Nelson Carvalho. Estudos do lazer: uma introdução. Campinas: Autores Associados. (Coleção educação física e esportes), 1996.

MARCELLINO, Nelson Carvalho. Lazer e educação. 13. ed. Campinas: Papirus, 2008.

Estudo do Lazer: uma introdução. Campinas: Autores associados 2002.

Lazer e cultura: algumas aproximações. In: (Org.) Lazer e cultura.

Campinas: Alínea, 2007. p.9-30.

MATOS, Lucília da Silva. Belém: do direito ao lazer ao direito à cidade. In: Lazer e Esporte: Políticas Públicas. MARCELLINO, Nelson Carvalho (Org.). 2. ed. Campinas: Autores Associados, 2001.

et al. Brinquedos de saúde: educação popular e animação cultural com a população em situação de rua de Belém. Revista brasileira de estudos do lazer, v. 5 , n. 1, p. 42-56, jan./ abr., 2018.

MAYOR, Sarah Teixeira; ISAYAMA, Hélder Ferreira O lazer do brasileiro: sexo, estado civil e escolaridade. In: STOPPA, Edmur Antonio; ISAYAMA, Hélder Ferreira (Org.). Lazer no Brasil: representações e concretizações das vivências cotidianas. Campinas: Autores Associados, 2017, p.19-36.

MELO, Vitor Andrade; ALVES JUNIOR, Edmundo de Drummond. Introdução ao lazer. Barueri: Manole, 2003.

A animação cultural: conceitos e propostas. Campinas: Papirus, 2006.

MELO, Vitor Andrade. Arte e lazer: desafios para romper o abismo. In: Marcellino, Nelson Carvalho (Org.). Lazer e cultura. Campinas: Alínea, 2007. p. 65-87.

MÉLLO, Ricardo Pimentel. Cuidado em saúde com arte-vibrátil: os estranhamentos criativos. In: MATOS, Lucília da Silva et al. Brinquedos de Saúde: experiências de educação e cuidado na produção de vida. Belém: Pala-Tatu, 2019, p. 231-251.

MESSENBERG, Debora. O paradoxo da democracia: A participação política dos alunos da Universidade de Brasília. Civitas, Rev. Ciênc. Soc., Porto Alegre, v. 15, n. 1, p. e1e23, Mar. 2015.2 Disponível: http://www.scielo.br/scielo.php?script=sci_arttext\&pid=S151960892015000100130\&ln $\mathrm{g}=\mathrm{en} \& \mathrm{nrm}=\mathrm{iso}$. Acesso em 09 de ago 2020.

MINAYO, Maria Cecília de Souza. (Org.). Pesquisa Social: teoria, método e criatividade. Petrópolis: Vozes, 2003.

MORAES, Melissa Machado de (org). Os impactos da pandemia e sua relação com o trabalho. Porto Alegre: Artmed, 2020. (Coleção o trabalho e as medidas de contenção da COVID-19: contribuições da Psicologia Organizacional e do Trabalho).

licere, Belo Horizonte, v.23, n.3, set/2020. 
PORRECA, Wladimir. Espiritualidade/Religiosidade: possíveis companhias nos desafios pandêmico - COVID-19. Caderno De Administração, 28, 141-146, 2020 Disponível em: https://periodicos.uem.br/ojs/index.php/CadAdm/article/view/53632. Acesso em: 20 jul 2020.

ROSA, Tatiane da Silva. Lazer: concepções e vivências de uma juventude. 2006. 112f. Dissertação (Mestrado em Educação), Universidade Federal do Rio Grande do Sul, 2006.

ROSA, Maria Cristina; SILVA, Marcone Rodrigues da. Esfera da obrigação: em destaque família/filhos, compromissos religiosos e compromissos políticos/sociais. In: STOPPA, Edmur Antonio; ISAYAMA, Hélder Ferreira (Org.). Lazer no Brasil: representações e concretizações das vivências cotidianas. Campinas: autores associados, 2017, p. 65-80.

SANTOS, Boaventura de Sousa. Tudo o que é sólido desmancha no ar. In: TOSTES, Anjuli e FILHO, Hugo Melo (Org.) Quarentena: reflexões sobre a pandemia e depois. Bauru: Editora Canal 6 Editora, 2020.

SCHMIDT, Beatriz et al. Saúde mental e intervenções psicológicas diante da pandemia do novo coronavírus (COVID-19). Estud. Psicol., Campinas , v. 37, e200063, 2020

Disponível em http://www.scielo.br/scielo.php?script=sci_arttext\&pid=S0103166X2020000100501\&ln $\mathrm{g}=\mathrm{en} \& \mathrm{nrm}=$ iso. Acesso em: 09 ago. 2020.

SCHWARTZ, Gisele Maria. O conteúdo virtual do lazer: contemporizando Dumazedier. Licere, Belo Horizonte, v. 6, n.2, p.23-32, 2003.

SECRETARIA DE SAÚDE DO ESTADO DO PARÁ. Dados da Vigilância Epidemiológica - SESPA. Disponível em: https://www.saude.pa.gov.br/coronavirus/. Acesso em: 07 ago 2020.

SILVA, Silvio Ricardo da. Apresentação. In: STOPPA, Edmur Antonio; ISAYAMA, Hélder F. (Org.) Lazer no Brasil: representações e concretizações das vivências cotidianas. Campinas: autores associados, 2017, p.1-2.

SILVEIRA, et al. Ensaio teórico, conceitual e provocativo Pandemia: (mesmos) modos de morar e trabalhar? Revista Políticas Públicas \& Cidades, Belo Horizonte, 2020, abril/dezembro, Volume Especial, p.1-5. Disponível em: https://cidadepandemia.com.br/2020/06/22/pandemia-mesmos-modos-de-morar-e-trabalhar-suzanamaria-renan-rossi-e-gabriel-vuono/ Acesso em: 08 ago 2020.

SOUSA, Luana Passos de; GUEDES, Dyeggo Rocha. A desigual divisão sexual do trabalho: um olhar sobre a última década. Estud. av. , São Paulo, v. 30, n. 87, p. 123-139, agosto de 2016.2 Disponível em http://www.scielo.br/scielo.php?script=sci_arttext\&pid=S010340142016000200123\&ln $\mathrm{g}=\mathrm{en} \& \mathrm{nrm}=\mathrm{iso}$. Acesso em: 09 ago. 2020.

STOPPA, Edmur A.; ISAYAMA, Hélder F. (Org.). Lazer no Brasil: representações e concretizações das vivências cotidianas. Campinas: autores associados, 2017.

TAVARES, Cássia Quelho. Dimensões do cuidado na perspectiva da espiritualidade durante a pandemia pelo novo coronavírus (COVID-19). J Health NPEPS. 2020; v5, n. 
1, p.1-4. Disponível em: http://docs.bvsalud.org/biblioref/2020/04/1095168/4517-15. 943-1-pb.pdf Acesso em: 20 jul. 2020.

UNIVERSIDADE FEDERAL DE PELOTAS. COVID-19 no Brasil: várias epidemias num só país Primeira fase do EPICOVID19 reforça preocupação com a região Norte. Disponível em: https://epidemio ufpel.org.br/uploads/downloads/276e0cffc2783c68f57b70920fd2acfb.pdf. Acesso em: 10 jul 2020.

UNIVERSIDADE FEDERAL DO PARÁ. Análise da evolução da pandemia de COVID-19 no Brasil - O Estado do Pará (NOTA TECNICA 02\2020). Disponível em:https://portal.ufpa.br/images/docs/nota_tecnica_COVID19_RMB_01052020_VFina 1.pdfAcesso em: 01 de ago de 2020.

WERNECK, Christiane Luce. Lazer, trabalho e educação: relações históricas, questões contemporâneas. Belo Horizonte: UFMG-CELAR, 2000.

WERNECK, Guilherme Loureiro; CARVALHO, Marilia Sá. A pandemia de COVID-19 no Brasil: crônica de uma crise sanitária anunciada. Cafajeste. Saúde Pública, Rio de Janeiro, v. 36, n. 5, e00068820, 2020. Disponível em http://www.scielo.br/scielo.php?script=sci_arttext\&pid=S0102311X2020000500101\&ln $\mathrm{g}=\mathrm{en} \& \mathrm{nrm}=$ iso. Acesso em: 09 ago. 2020.

\section{Endereço dos/as Autores/as:}

Lucília da Silva Matos

Universidade Federal do Pará - Campus Profissional

Rua Augusto Corrêa, n. 1, Guamá

Belém - PA - 66.075-110

Endereço Eletrônico: luciliasmatos@gmail.com

Welington da Costa Pinheiro

Universidade Federal do Pará - Campus Profissional

Rua Augusto Corrêa, n. 1, Guamá

Belém - PA - 66.075-110

Endereço Eletrônico: welingtoncpinheiro@ hotmail.com

Mirleide Chaar Bahia

Universidade Federal do Pará - Campus Profissional

Rua Augusto Corrêa, n. 1, Guamá

Belém - PA - 66.075-110

Endereço Eletrônico: mirleidebahia@gmail.com 